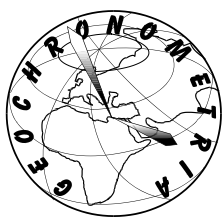

\title{
A REVIEW OF RADIOMETRIC ANALYSIS ON SOIL EROSION AND DEPOSITION STUDIES IN AFRICA
}

\author{
CAROLINE W. MAINA ${ }^{1,2}$, JOSEPH K. SANG ${ }^{2}$, BENEDICT M. MUTUA ${ }^{3}$ and JAMES M. RAUDE ${ }^{2}$ \\ ${ }^{I}$ Deparment of Agricultural Engineering, Egerton University, P.O. Box 536-20115, Egerton, Kenya \\ ${ }^{2}$ Soil, Water and Environmental Engineering Department, JKUAT, P.O. Box 62000-00200, Nairobi, Kenya \\ ${ }^{3}$ Kibabii University, P.O. Box 1699-50200, Bungoma, Kenya
}

\begin{abstract}
Soil erosion is one of the main soil degradation phenomena that threaten sustainable use of soil productivity thus affecting food security. In addition, it leads to reservoir storage capacity loss because of sedimentation. This not only affects water quantity but also water quality. Worldwide, annual loss in reservoir storage capacity due to sedimentation is 0.5 to $1 \%$. Similarly, about $27 \%$ of land in Africa is largely degraded by erosion. As a result, there is need to minimize soil erosion and deposition through site specific estimation of soil erosion and deposition rates in the reservoirs. To achieve this, Fallout RadioNuclides (FRNs) are some of the methods in use. The most common radionuclides include; ${ }^{137} \mathrm{Cs},{ }^{210} \mathrm{~Pb}$ and ${ }^{7} \mathrm{Be}$. Only few countries in Africa have exploited these FRNs. In these countries, ${ }^{137} \mathrm{Cs}$ has been largely exploited but in some regions, it has been reported to be below minimum detection limit. Using ${ }^{137} \mathrm{Cs}$ and ${ }^{210} \mathrm{~Pb}$, maximum reference inventory in Africa is found to be 1450 and $2602 \mathrm{~Bq} / \mathrm{m}^{2}$, respectively. However, there is minimal application of ${ }^{7} \mathrm{Be}$ within the continent. Also, very little has been done in Africa to assess chronology and sedimentation rates of reservoirs using FRNs measured from sediment cores. In conclusion, a gap still exists on FRNs application in Africa in assessing soil erosion, deposition and reservoir sedimentation.
\end{abstract}

Keywords: soil erosion, deposition, fallout radionuclides, Caesium-137, Lead-210, Beryllium-7.

\section{INTRODUCTION}

Worldwide, agriculture is not only being affected by global warming and climate change but also accelerated soil erosion and the associated soil degradation (Walling, 1998; Marestoni et al., 2009). Accelerated soil erosion is one of the main environmental problem (Zapata and Agudo, 2000; Konz et al., 2010; Othman and Ismail, 2012) that largely affects sustainable use of soil and water resources (Patrocinio and Andrello, 2009). Soil erosion is a major threat to soil productivity and represents the main

Corresponding author: C.W. Maina

e-mail: caroline.maina@egerton.ac.ke mechanism of land degradation worldwide (IAEA, 2014). According to ICOLD (2009), 27\% of land in Africa is degraded, out of which $65 \%$ of agricultural land is degraded due to erosion and/or chemical and physical damage. In addition, soil erosion is reported by Collins et al. (2001) as a serious environmental problem in many African countries. The severe soil erosion and degradation largely affect food security in Sub-Saharan Africa (Dercon et al., 2012). This has been attributed to many developing countries in Africa having experienced expansion of agriculture on to marginal land. To tackle the loss of productive soil, quantification of soil erosion rates is a major requirement (Poręba, 2006; Porto et al., 2014b). Further, soil erosion and deposition have offsite effects related to loss of reservoir storage capacity. In water resources, most reservoirs do not fulfil their func- 
tions due to capacity loss and reduction in water quality resulting from sedimentation (Marestoni et al., 2009; Apostu et al., 2012).

Globally, the loss of reservoir storage capacity has been approximated to $0.5-1 \%$ per year (ICOLD, 2009). This greatly affects the reservoir functions like water supply for domestic, irrigation and hydropower generation. On the other hand, water quality is lowered especially when the source of sediments is from agricultural farms or contaminated environment. The eroded sediment acts as a vector for the transportation of agrochemicals from agricultural lands to water bodies (Porto and Walling, 2012). Further, due to climate change and global warming, water erosion is expected to be on the increase (Mabit et al., 2014c). An increase in extreme daily rainfall has been experienced in many catchments and this may lead to severe loss of soil in cultivated land. As a result, there is need to estimate the chronology of sediment production especially in most catchments within developing countries where the sedimentation rates of reservoirs are inadequately documented. Also, soil erosion rate data at different temporal changes is required so as to aid in quantifying potential changes that might occur when different land uses have been adopted and with change in climate (Li et al., 2010; Benmansour et al., 2013).

To reconstruct the history on impacts of anthropogenic activities in water bodies, sediment collected from lakes play a major role. The collected sediments also aids in establishing accurate chronologies of sedimentation and in study of sediment accumulation rates (IAEA, 2003). The use of radionuclides in soil erosion and deposition studies allows assessment of soil erosion and deposition within a catchment to be obtained with minimal field visits (IAEA, 1998; Walling, 1999; Saç and İçhedef, 2015). The Fallout radionuclides (FRNs) is a costeffective tool that is useful in studying soil redistribution due to erosion within the landscape from plot to basin scale. Also, the information derived from FRNs is useful in complementing information provided by conventional erosion measurements and modelling (IAEA, 2014).

The traditional methods of quantifying soil erosion rate are labour intensive and require long term monitoring programs (Poręba, 2006). Walling and Quine (1992), reported that existing soil erosion monitoring techniques has many limitations in terms of their potential to provide information on longer term soil loss rates over large areas. In addition, in most developing countries especially in Africa, continuous sediment gauging has not been done consistently for longer periods. To tackle these challenges, FRNs have been adopted in many developed countries to assess soil erosion magnitudes (Zapata and Agudo, 2000; Dercon et al., 2012; Porto and Walling, 2012) but little has been done in Africa. Therefore, there is need to explore the use of FRNs in assessing soil erosion rates and patterns of soil redistribution/deposition. The theory of using isotopes in soil erosion analysis is based on their characteristics. The isotopes reach the soil through precipitation and they are then strongly bound to the soil particles where they can only be moved by erosion ( Saç and İçhedef, 2015). The use of radionuclides in determining soil erosion rates, aids in modelling soil redistribution within the catchment or the landscape (Nouira et al., 2003; Porto et al., 2014b). Further, use of the radionuclides provides a fast and robust way of determining spatial soil redistribution (Meusburger et al., 2013). Use of FRNs, provides data that is useful in targeting the areas with high erosion and sediments transfers. The identified areas can then be targeted for land management and conservation practices thus reducing the negative impacts resulting from soil erosion. Successful use of FRNs require suitable and statistically sound sampling procedures (Mabit et al., 2013). This highly reduces the limitations associated with the use of FRNs in soil redistribution studies. Care and proper selection of reference sites is required for proper application of FRNs in assessing soil redistribution. In addition, there is need for more research in various parts of the world on use of FRNs and assessing their limitations as challenged by Parsons and Foster, 2011. This would lead to an improved and highly viable method of assessing erosion and deposition.

In Africa and most developing countries, very few studies have been conducted in using FRNs to evaluate erosion and deposition magnitudes. The aim of this paper is to provide information on application of FRNs in soil erosion, deposition and reservoir sedimentation studies in Africa.

\section{FALLOUT RADIONUCLIDES (FRNS)}

Some of the highly used radionuclides include; ${ }^{137} \mathrm{Cs}$, ${ }^{210} \mathrm{~Pb}$ and ${ }^{7} \mathrm{Be}$ (Dercon et al., 2012; Porto et al., 2014a). In applying these nuclides, selection of a reference site is of critical importance. This aids in improving validity of the technique to accurately quantify erosion and deposition. To convert ${ }^{137} \mathrm{Cs},{ }^{210} \mathrm{~Pb}$ and ${ }^{7} \mathrm{Be}$ activity to soil erosion, deposition or distribution rate, several models have been developed (Walling et al., 2002; Walling et al., 2014) and they are summarised in Table 1. For successful application of the models, a sound understanding of the models and the meaning and derivation of their parameters is highly required to reduce the limitation and uncertainty of information obtained.

\section{The use of ${ }^{137} \mathrm{Cs}$ in soil erosion and deposition studies}

The ${ }^{137} \mathrm{Cs}$ is an artificial radionuclide which primarily originated from nuclear weapons testing (Ritchie and Mchenry, 1990; Walling, 1998). It was first detected in early 1950s peaking in early 1960s (Stefano et al., 1999; Mabit et al., 2014a) before the nuclear test ban treaty. However, it declined to very low levels in the mid-1970s. The ${ }^{137} \mathrm{Cs}$ isotope has a half-life of about 30 years (Poręba, 2006). Gellis et al. (2006), Walling (1998), Mahawatte and Abeynayake (2010) observed that there is 
Table 1. Models used in Converting FRNs to Erosion /depositional rates.

\begin{tabular}{|c|c|c|c|c|}
\hline Model & Input parameter & FRNs and site used & Advantage & Limitation \\
\hline $\begin{array}{l}\text { Proportional } \\
\text { model }\end{array}$ & Plough depth, bulk density & ${ }^{137} \mathrm{Cs}$ (Cultivated) & $\begin{array}{l}\text { 1. Requires few input } \\
\text { parameters } \\
\text { 2. Easy to apply }\end{array}$ & $\begin{array}{l}\text { 1. Oversimplification of }{ }^{137} \mathrm{Cs} \\
\text { accumulation in the soil } \\
\text { 2. Model does not account for } \\
\text { dilution of }{ }^{137} \mathrm{Cs} \text { concentrations in } \\
\text { the soil }\end{array}$ \\
\hline $\begin{array}{l}\text { Mass Balance } \\
\text { Model } 1 \\
\text { (MBM1) }\end{array}$ & $\begin{array}{l}\text { Plough depth, bulk density, year of } \\
\text { tillage commencement proportional } \\
\text { factor, relaxation depth, annual fallout } \\
\text { flux* }\end{array}$ & ${ }^{137} \mathrm{Cs}$ (Cultivated) & $\begin{array}{l}\text { 1. Accounts for progressive } \\
\text { reduction in the }{ }^{137} \mathrm{Cs} \\
\text { concentration of the soil }\end{array}$ & $\begin{array}{l}\text { 1. Model does not account for } \\
\text { removal of freshly deposited }{ }^{137} \mathrm{Cs} \\
\text { by erosion during a rainfall event } \\
\text { 2. The model assumes that } \\
\text { concentration of }{ }^{137} \mathrm{Cs} \text { in eroded } \\
\text { sediments remains constant } \\
\text { through time. Also, the } \\
\text { concentration of deposited } \\
\text { sediment is assumed to be } \\
\text { constant }\end{array}$ \\
\hline $\begin{array}{l}\text { Mass balance } \\
\text { model } 2 \\
(\mathrm{MBM} 2)\end{array}$ & $\begin{array}{l}\text { Tillage depth, tillage constant, propor- } \\
\text { tional factor, tillage relaxation depth, } \\
\text { slope length and slope gradient for } \\
\text { each section of the transect, annual } \\
\text { fallout flux* }\end{array}$ & $\begin{array}{l}{ }^{137} \mathrm{Cs} \text { (Cultivated) and } \\
\text { 210Pb (Cultivated) }\end{array}$ & $\begin{array}{l}\text { 1. Accounts for tillage effects } \\
\text { 2. Caters for }{ }^{137} \mathrm{Cs} \text { dilution in } \\
\text { the plough layer } \\
\text { 3. Obtained results are more } \\
\text { realistic than from the previous } \\
\text { models }\end{array}$ & $\begin{array}{l}\text { More data is required than from the } \\
\text { previous models }\end{array}$ \\
\hline $\begin{array}{l}\text { Mass Balance } \\
\text { Model } 3 \\
\text { (MBM3) }\end{array}$ & $\begin{array}{l}\text { In addition to MB2 parameters Diffu- } \\
\text { sion coefficient, relaxation depth, } \\
\text { migration, coefficient, annual fallout } \\
\text { flux }\end{array}$ & $\begin{array}{l}{ }^{137} \mathrm{Cs} \text { (Cultivated) and } \\
{ }^{210} \mathrm{~Pb} \text { (Cultivated) }\end{array}$ & $\begin{array}{l}\text { 1. Results from this model are } \\
\text { closer to reality } \\
\text { 2. It accounts for tillage } \\
\text { redistribution in flow direction }\end{array}$ & The model is data intensive \\
\hline $\begin{array}{l}\text { Profile shape } \\
\text { model }\end{array}$ & $\begin{array}{l}\text { Profile shape factor, } \\
\text { Mass depth of soil }\end{array}$ & $\begin{array}{l}{ }^{137} \mathrm{Cs} \text { (Uncultivated) } \\
{ }^{7} \mathrm{Be} \text { (Cultivated) }\end{array}$ & Simple and easy to use & $\begin{array}{l}\text { Does not account for temporal } \\
\text { variation of }{ }^{137} \mathrm{Cs}\end{array}$ \\
\hline $\begin{array}{l}\text { Diffusion and } \\
\text { migration and } \\
\text { model }\end{array}$ & $\begin{array}{l}\text { Diffusion coefficient, Migration rate, } \\
\text { /retardation factor }\end{array}$ & 210Pb (Uncultivated) & $\begin{array}{l}\text { 1. Accounts of temporal } \\
\text { variation of depth profile } \\
\text { resulting from the time- } \\
\text { dependent fallout input }\end{array}$ & $\begin{array}{l}\text { Requires more time and data to } \\
\text { use }\end{array}$ \\
\hline
\end{tabular}

${ }^{*}$ required for ${ }^{137} \mathrm{Cs}$ only

a strong adsorption of ${ }^{137} \mathrm{Cs}$ by clay and organic matter in soils. According to Patrocinio and Andrello (2009) and Dercon et al. (2012) ${ }^{137} \mathrm{Cs}$ is useful in studying the sediment chronology since it is rapidly and strongly absorbed to fine particles of the soil. Also, the distribution of ${ }^{137} \mathrm{Cs}$ in the soil sediment profile is directly related to the chronology of sediment deposition. Its fallout deposition on land surface from atmospheric nuclear test occurs from rainfall. It is largely absorbed on finer organic and soil particles and it resists leaching through the soil profile (Walling et al., 1995). The profiles of ${ }^{137} \mathrm{Cs}$ in sediments give the deposition history that can be interpreted to assign calendar dates.

According to Mabit et al. (2014d) when assessing the redistribution rates of the soil using ${ }^{137} \mathrm{Cs}$, the measured values of ${ }^{137} \mathrm{Cs}$ in individual sampling points are compared with reference ${ }^{137} \mathrm{Cs}$ input. The reference inventory represents ${ }^{137} \mathrm{Cs}$ values measured in undisturbed sites where no erosion nor deposition has taken place (Othman and Ismail, 2012). To reduce the variability of data collected hence ensure that there is uniform local distribution of ${ }^{137} \mathrm{Cs}$, reference sites should be selected in the vicinity of the targeted fields that will be subsequently investigated (Mabit et al., 2013). Selecting appropriate local reference inventory is therefore a major requirement to successful use FRNS in soil erosion and deposition assessment. If the ${ }^{137} \mathrm{Cs}$ activity is lower than that of reference site, this signifies erosion. On the other hand, if the ${ }^{137} \mathrm{Cs}$ activity value is higher than that of the reference site, it signifies that soil deposition has taken place (Othman and Ismail, 2012; Porto et al., 2014a). Mostly, in natural uncultivated soils, the distribution of ${ }^{137} \mathrm{Cs}$ has an exponential decline with soil depth.

According to Walling and Quine (1992), a sharp decline in ${ }^{137} \mathrm{Cs}$ activity is observed with increasing depth. Minimum vertical translocation of ${ }^{137} \mathrm{Cs}$ was also reported. In different soils studied, more than $75 \%$ of the total inventory occurs in the top $15 \mathrm{~cm}$.

The key assumption that affects application of ${ }^{137} \mathrm{Cs}$ is that uniform spatial distribution of the nuclide exists (Parsons and Foster, 2011). Local variability of ${ }^{137} \mathrm{Cs}$ is influenced by individual storm. The application assumes that the patterns from individual storms over extended period leads to uniform local pattern of total fallout (Walling and Quine, 1992).In addition, it is assumed that redistribution of ${ }^{137} \mathrm{Cs}$ indicates that there is soil move- 
ment and that ${ }^{137} \mathrm{Cs}$ is rapidly adsorbed by soil particles (Mabit et al., 2014a; Walling and Quine, 1992).

Despite these assumptions the use of FRNs provides more information on soil and deposition status in different sites. This method provides an immense potential in data scarce regions. To further improve on the findings the choice of reference sites is critical. Parsons and Foster (2011) reported that use of reference sites in assessing soil erosion and deposition limits the application of FRNs. They argued that samples collected from the same reference sites give high variability of ${ }^{137} \mathrm{Cs}$. Another limitation raised by Parsons and Foster (2011), on the use of ${ }^{137} \mathrm{Cs}$ is its variability in areas affected by the Chernobyl accident, where additional radio-caesium fallout inputs in 1986 can complicate interpretation of ${ }^{137} \mathrm{Cs}$ measurements. In such areas, use of ${ }^{210} \mathrm{~Pb}$ alone or in combination with ${ }^{137} \mathrm{Cs}$ in assessing erosion and deposition rates would be highly encouraged."

Although, possibilities of using ${ }^{137} \mathrm{Cs}$ in assessing soil erosion and sedimentation in developing countries was discussed in 1995 (IAEA, 1998) very little has been done in most African countries. Since nuclear fallout was low in southern hemisphere regions, it has been noted that ${ }^{137} \mathrm{Cs}$, is on decline compared to northern hemisphere (Ritchie and Mchenry, 1990; Walling, 1998; Stefano et al., 1999; Dercon et al., 2012). A great part of subSaharan Africa falls on the southern hemisphere. Hence there is difficulty in using ${ }^{137} \mathrm{Cs}$, for soil erosion and deposition, since the quantities measured are very low or in some cases below detection limit. As a result, erosion rates can be assessed using a natural radionuclide such as ${ }^{210} \mathrm{~Pb}$.

\section{Use of ${ }^{210} \mathrm{~Pb}$ in Soil erosion and deposition}

This is a natural radionuclide that originates from the decay of ${ }^{222} \mathrm{Rn}$, a stable isotope of Radon ( Rn) that occurs in soil and the atmosphere. It is a natural radioactive form of lead found in small quantities in most soils as part of uranium decay series and has a half-life of 22.3 years (Lubis, 2006; Porto et al., 2006). According to Guzman et al. $(2013){ }^{210} \mathrm{~Pb}$ is usually derived from radioactive decay of ${ }^{222} \mathrm{Rn}$ (Radon 222) gas daughter of Radium 226 $\left({ }^{226} \mathrm{Ra}\right)$. The ${ }^{226} \mathrm{Ra}$ occurs naturally in soils and rocks and generates ${ }^{210} \mathrm{~Pb}$ that is in equilibrium with its parent material (Zhang et al., 2014). The soil and sediment samples for measuring ${ }^{210} \mathrm{~Pb}$ is stored for about a month before analysis so as to achieve equilibrium of ${ }^{226} \mathrm{Ra}$ and its ${ }^{222} \mathrm{Rn}$ (Shakhashiro and Mabit, 2011; Mabit et al., 2014c). The concentration of ${ }^{210} \mathrm{~Pb}$ is greatest at the surface in uncultivated land because of its continuous replenishment at the soil surface. Also, it has an exponential reduction in activity below the surface (Zhang et al., 2007). The nuclide is useful in establishing the chronology of sediment deposits and estimating the rate of accumulation of such deposits.

The rate of ${ }^{210} \mathrm{~Pb}$ activity declines with depth in a core and it aids in establishing an age depth relationship and the rate of sediment accumulation. In cases where accumulation rates are high, the ${ }^{210} \mathrm{~Pb}$ activity declines slowly with depth. On the other hand, if accumulation rates are low, the ${ }^{210} \mathrm{~Pb}$ activity reduces rapidly with depth (Walling et al., 2002). The ${ }^{210} \mathrm{~Pb}$ is useful in estimating the soil redistribution for up to 100 years (Zheng et al., 2006; Benmansour et al., 2014; Mabit et al., 2014a) a period longer than that of ${ }^{137} \mathrm{Cs}$. Further, ${ }^{210} \mathrm{~Pb}$ is useful in areas where low ${ }^{137} \mathrm{Cs}$ concentration is likely to pose a problem especially in the southern hemisphere (Porto et al., 2006; Shakhashiro and Mabit, 2011).

A research conducted in different regions under Coordinated Research Project (CRP), aimed at investigating the potential of using ${ }^{210} \mathrm{~Pb}$ measurements to estimate soil redistribution rates. It reported that only $31 \%$ of the participants provided acceptable results for total ${ }^{210} \mathrm{~Pb}$ analyes (IAEA, 2011). These findings are further supported by Golosov et al. (2011) who reported that ${ }^{210} \mathrm{~Pb}$ was characterised by high local variability compared to ${ }^{137} \mathrm{Cs}$. Almost similar observation were reported by Mabit et al. (2014c) where a major limitation in use of ${ }^{210} \mathrm{~Pb}$ was reported to be the difficulty experienced in accurately analysing the nuclide using gamma spectrometry. There are seasonal variations of ${ }^{210} \mathrm{~Pb}$ in the atmosphere and this affects its use in some parts of the world. Therefore, there is need for more research to test and validate the use of ${ }^{210} \mathrm{Pbex}$ for documenting soil redistribution rates under a range of different environmental and climatic conditions (Benmansour et al., 2014).

Although use of ${ }^{210} \mathrm{~Pb}$ and ${ }^{137} \mathrm{Cs}$ in erosion assessment over longer periods is possible, their application for short time period is very limited. However, other radionuclides such as ${ }^{7}$ Be nuclide can be used.

\section{${ }^{7} \mathrm{Be}$ use in soil erosion and deposition studies}

This is a naturally occurring cosmogenic radionuclide that is produced in the stratosphere and troposphere when oxygen and nitrogen spallate. The nuclide is then deposited as fallout (Guzman et al., 2013). According to Marestoni et al. (2009), ${ }^{7} \mathrm{Be}$ is a radionuclide that is useful in assessing soil erosion over a short period and in identifying the newly deposited sediment. It is mostly detectable near the surface of the sediment samples and should be counted soon enough after a sample collection since it has a half-life of 53.3 days (Zapata and Agudo, 2000). According to Wilkinson et al. (2006), the nuclide is not found below $20 \mathrm{~mm}$ of any soil and the radionuclide is useful for surface sediments recovery. The concentration of ${ }^{7} \mathrm{Be}$ in the soil is influenced by atmospheric processes, vertical transport in the troposphere and horizontal transport of subtropical and middle latitudes to the tropics and Polar Regions. In addition, it is used in studying mass exchange between troposphere and stratosphere, wet and dry deposition (Marestoni et al., 2009). The main fallout process of ${ }^{7} \mathrm{Be}$ is through precipitation which takes $95 \%$ of the total. When ${ }^{7} \mathrm{Be}$ is used in assessing sedimentation, the stable, eroding and aggrading sites are well 
distinguished using both their total inventory and the vertical profile distribution. An exponential decline in activity concentration and areal activity density with depth is usually experienced. Loss of ${ }^{7} \mathrm{Be}$ from surface soil indicates that soil erosion has taken place and this removes the upper section of the exponential profile leading to a reduction in overall inventory (Mabit et al., 2014b). The ${ }^{7} \mathrm{Be}$ nuclide are useful in assessing the effectiveness of recent soil erosion conservation practices. They are also used to document erosion and sedimentation rates associated with rainfall events. The application of ${ }^{7} \mathrm{Be}$ has two key assumptions; the input of ${ }^{7} \mathrm{Be}$ associated with the erosional or depositional event is spatially uniform, and, that any pre-existing ${ }^{7} \mathrm{Be}$ is uniformly distributed across the area under investigation. Since the method is dependent on individual event, the ${ }^{7} \mathrm{Be}$ inventories may be low in arid and semi-arid area of land. Though the nuclide has been used in soil erosion, redistribution and deposition analyses, its application in Africa is very limited.

\section{APPLICATION OF FALLOUT RADIONU- CLIDES IN AFRICA}

This section reviews application of FRNs in assessing soil erosion and reservoir sedimentation in Africa. In this, the continent was divided into four regions namely; Eastern Africa, Northern Africa, Western Africa and Southern Africa. During the review, one recent project was found to cover almost all the above-named regions i.e. were well distributed in the African region. The project has been implemented in 10 countries namely; Algeria, Benin, Cote d'ivore, Madagascar, Mali, Morocco, Senegal, Tunisia, Uganda and Zimbabwe. It focused on using Fallout radionuclide's $\left({ }^{137} \mathrm{Cs},{ }^{210} \mathrm{~Pb}\right.$ and $\left.{ }^{7} \mathrm{Be}\right)$ in quantifying African soil degradation, soil erosion and sediment redistribution rates within agricultural landscapes. The results from this IAEA conducted research project had not yet been published at the period this review paper was compiled. In this paper, the summary of radionuclide activities within the reference site is presented in Table 2. In addition, Fig. 1 shows the distribution of the radionuclide use in Africa. The other findings for different application of FRNs in African region were presented as follows;

\section{Eastern Africa}

In this region Uganda, Kenya and Ethiopia were found to have some information on use of FRNs in soil and sediment studies. For instance, Ruecker et al. (2008) examined the potential of using ${ }^{137} \mathrm{Cs}$ technique to assess soil redistribution rates in humid tropics of Uganda. The ${ }^{137} \mathrm{Cs}$ inventory was found to be 392 and $439 \mathrm{~Bq} / \mathrm{m}^{2}$ for Kongta and Magada reference sites, respectively. These results were found to be within the range of globally interpolated ${ }^{137} \mathrm{Cs}$ inventory of the region. The average ${ }^{137} \mathrm{Cs}$ inventory within Kongta and Magada was reported to be $200 \pm 100$ and $400 \pm 100 \mathrm{~Bq} / \mathrm{m}^{2}$ respectively. Within the Kongta and Magada sites the mean ${ }^{137} \mathrm{Cs}$ inventory was reported to be $202 \pm 87.2$ and $382 \pm 155 \mathrm{~Bq} / \mathrm{m}^{2}$ respectively. Further, the net soil redistribution of the two sites (Kongta and Magada) indicated that there was soil loss of $21 \pm 12.2 \mathrm{t} / \mathrm{ha} / \mathrm{yr}$ and $4.5 \pm 2.3 \mathrm{t} / \mathrm{ha} / \mathrm{yr}$, respectively. Soil deposition within Kongta and Magada was also reported to be $5.8 \pm 0.9$ and $6.3 \pm 4.3 \mathrm{t} / \mathrm{ha} / \mathrm{yr}$ respectively. It was concluded that ${ }^{137} \mathrm{Cs}$ method was applicable in estimating soil redistribution within humid tropics of Africa. The study found out that peak hillslope erosion for Kongta and Magada were 44.6 t/ha/yr and $36.3 \mathrm{t} / \mathrm{ha} / \mathrm{yr}$ while sedimentation rates were $6.4 \mathrm{t} / \mathrm{ha} / \mathrm{yr}$ and $25 \mathrm{t} / \mathrm{ha} / \mathrm{yr}$ respectively. The reduced soil deposition and increased soil erosion in Kongta is because the site is on steep hillslope. It was also reported that there had been no documented application of this method in the humid

Table 2. Summary of radionuclide activity in reference sites.

\begin{tabular}{|c|c|c|c|}
\hline Country (Region) & Author & $\begin{array}{l}\text { Reference inventory } \\
\left(\mathrm{Bq} / \mathrm{m}^{2}\right)\end{array}$ & $\overline{\text { FRN used }}$ \\
\hline $\begin{array}{r}\text { Uganda (Kongta) } \\
\text { (Magada) }\end{array}$ & Ruecker et al., 2008 & $\begin{array}{l}392 \\
439 \\
\end{array}$ & $\begin{array}{l}{ }^{137} \mathrm{Cs} \\
{ }^{137} \mathrm{Cs}\end{array}$ \\
\hline Kenya & Jeff and Shepherd, 2009 & $<30$ (Below minimum detectable limits) & ${ }^{137} \mathrm{Cs}$ \\
\hline $\begin{array}{l}\text { Ethiopia } \\
\text { (Kefa zone) }\end{array}$ & Denboba, 2005 & $2064 \pm 112$ & $137 \mathrm{Cs}$ \\
\hline Morocco (Boussouab) & $\begin{array}{l}\text { Sadiki et al., } 2007 \\
\text { Benmansour et al., } 2013\end{array}$ & $\begin{array}{c}1450 \\
3305 \\
1445 \\
101 \\
\end{array}$ & $\begin{array}{c}{ }^{137} \mathrm{Cs} \\
{ }^{210} \mathrm{~Pb} \\
{ }^{137} \mathrm{Cs} \\
{ }^{7} \mathrm{Be} \\
\end{array}$ \\
\hline Bukina Faso (Dano and Wahable) & Schmengler, 2011 & $729 \pm 14$ & ${ }^{137} \mathrm{Cs}$ \\
\hline Ghana & Pennock, 2000 & 925.1 & ${ }^{137} \mathrm{Cs}$ \\
\hline Niger (Southwest) & Chappell et al., 1998 & $2066 \pm 125$ & ${ }^{137} \mathrm{Cs}$ \\
\hline Zimbabwe & Quine et al., 1993 & 30 & ${ }^{137} \mathrm{Cs}$ \\
\hline Zambia (Kaleya) & $\begin{array}{l}\text { Walling et al., 2003 } \\
\text { (Collins et al., 2001) }\end{array}$ & $\begin{array}{c}2602 \\
202.0 \pm 22.8\end{array}$ & $\begin{array}{l}{ }^{210} \mathrm{~Pb} \\
{ }^{137} \mathrm{Cs}\end{array}$ \\
\hline
\end{tabular}




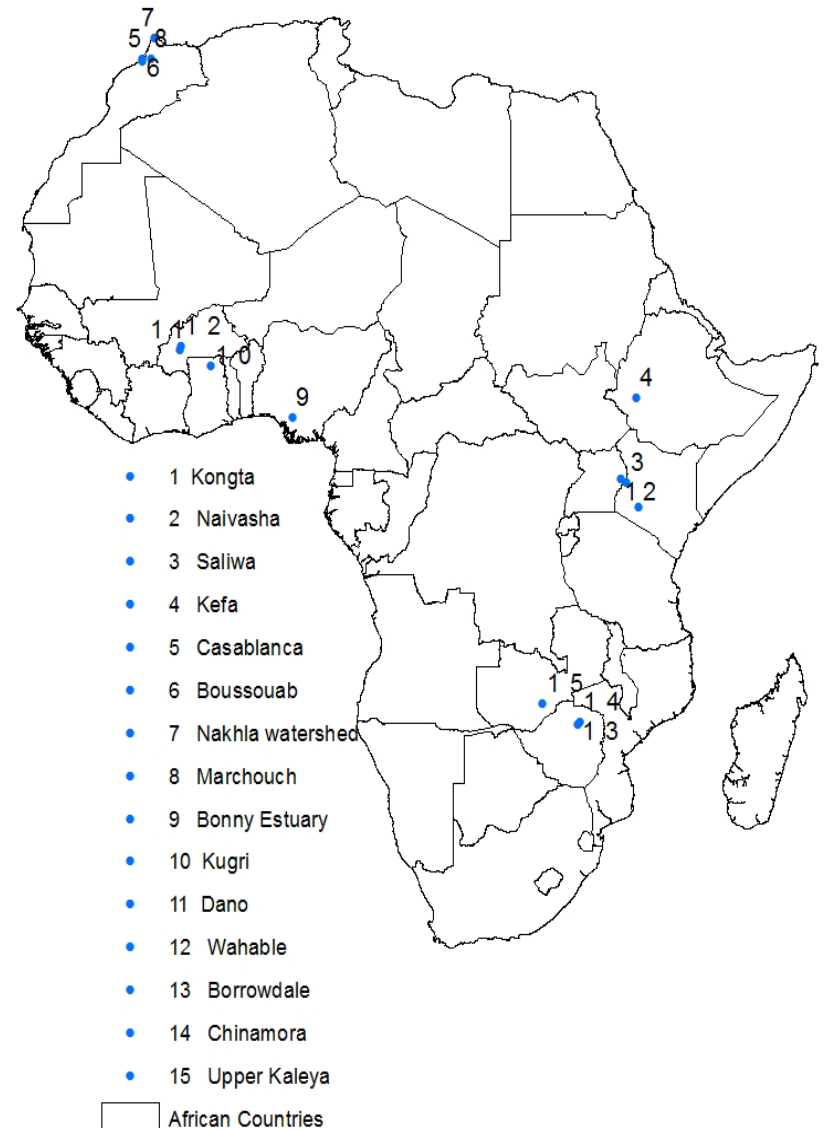

Fig. 1. Map of Africa showing Regions where FRNs have been used for soil erosion and Reservoir sedimentation analysis.

tropics of Africa. The low application of this method could be due to the region being on the southern hemisphere where ${ }^{137} \mathrm{Cs}$ inventories are almost one order of magnitude lower than in the northern hemisphere (Walling and He, 1999; Collins et al., 2001; Walling et al., 2002). Ruecker et al. (2008) reported difficulty in selecting reference sites near the study area since intensive land use in this climatic zone has been practiced leaving almost all areas being disturbed. They also pointed out that lack of access to institutions with gamma spectrometer detectors in this region further affected widespread applicability of the ${ }^{137} \mathrm{Cs}$ method.

Further, in Lake Naivasha, Kenya, a sediment core sample was analysed by Stoof-Leichsenring et al. (2011) who reported that, total ${ }^{210} \mathrm{~Pb}$ activity reached equilibrium with ${ }^{226} \mathrm{Ra}$ at a depth of about $33 \mathrm{~cm}$. Also, the unsupported ${ }^{210} \mathrm{~Pb}$ was reported to reduce irregularly with depth but the concentration in the top $15 \mathrm{~cm}$ was relatively constant at a mean rate of $164 \mathrm{~Bq} / \mathrm{kg}$. Also, at a depth below $30 \mathrm{~cm}$, the concentration was found to be close or near the minimum detection limit. On the other hand, the ${ }^{137} \mathrm{Cs}$ concentration was found to be highest between depths $20-25 \mathrm{~cm}$. Stoof-Leichsenring et al. (2011) also used ${ }^{210} \mathrm{~Pb}$ dating to establish the core chronology that provided information for a period of $186 \mathrm{yr}$ history of natural and human induced environmental changes.

In addition, Jeff and Shepherd (2009) analysed ${ }^{137} \mathrm{Cs}$ soil samples in Sauwa river watershed, western Kenya. Four reference sites were selected in the study area and they consisted of sloped grassed pasture, thickly vegetated (Trees and shrubs) and two sites within Kapolete National forest. The sample depth intervals were too broad hence detailed soil profile analysis could not be undertaken. The samples were analysed for ${ }^{137} \mathrm{Cs}$ and ${ }^{210} \mathrm{~Pb}$ using standard laboratory procedures in IAEA standard reference material (IAEA - 300). The sample counts were taken for 21.7 to 26.1 hours depending on nuclide activity. They reported that most of the samples had low concentration of the nuclide which was well below minimum detection concentration limits of $30 \mathrm{~Bq} / \mathrm{kg}$. The ${ }^{137} \mathrm{Cs}$ was reported to be more concentrated in the upper few centimetres of the soil profile and this concentration decreased with soil depth. Further, little ${ }^{137} \mathrm{Cs}$ was detected below a soil depth of $20 \mathrm{~cm}$. The mean ${ }^{137} \mathrm{Cs}$ concentration was reported to be 1.68 and $4.15 \mathrm{~Bq} / \mathrm{kg}$ in eroded and noneroded sites. Within the top soils, $82 \%$ of samples had detectable level of ${ }^{137} \mathrm{Cs}$ while $33 \%$ had detectable levels within the sub soils. They confirmed the results by field visits that were conducted and $63 \%$ of the top soil was found to have been eroded. Almost similar findings were reported for Ethiopia by Denboba (2005).

Denboba (2005) conducted research on the high mountain forests in Kefa zone in southwest of Ethiopia, on the cultivated fields of selected subcatchments. The ${ }^{137} \mathrm{Cs}$ was used to estimate the rate of soil erosion and deposition. It was found that there was an exponential decline of ${ }^{137} \mathrm{Cs}$ activity with increase in depth. Further, $69 \%$ of ${ }^{137} \mathrm{Cs}$ inventory was found in the upper $10 \mathrm{~cm}$ of soil surface while $19 \%$ and $12 \%$ inventories were found in $20 \mathrm{~cm}$ and $30 \mathrm{~cm}$ subsurface layers, respectively. The mean reference inventory was found out to be larger than the assumed range of $200-500 \mathrm{~Bq} / \mathrm{m}^{2}$ (Collins et al., 2001) for the equitorial region. This pointed out the need of more studies within the equitorial region so as to understand the ${ }^{137} \mathrm{Cs}$ activity other than relying on the world interpolated ${ }^{137} \mathrm{Cs}$ activity inventories.

\section{Northern Africa}

The ${ }^{137}$ Cs was used by Sadiki et al. (2007) to quantify erosion rates and identify main factors involved in erosion process in Boussouab catchment, Eastern Rif Morocco. It was found out that at the sampling sites, the ${ }^{137} \mathrm{Cs}$ activity ranged between 245 and $3670 \mathrm{~Bq} / \mathrm{m}^{2}$. This indicated that in all sampling sites, erosion had taken place. In addition, soil loss was reported to be highly variable within land use and the variance ranged between 5.1 and $48.8 \mathrm{t} / \mathrm{ha} / \mathrm{yr}$. Further, the average soil loss was reported to increase by more than $100 \%$ when slope increased from $10^{\circ}$ to $25^{\circ}$ with loss of $17.7 \mathrm{t} / \mathrm{ha} / \mathrm{yr}$ and $40.8 \mathrm{t} / \mathrm{ha} / \mathrm{yr}$, respectively. The radiometric analysis 
proved useful in quantifying erosion rates and in examining the soil movement pattern.

This view is supported by Benmansour et al. (2013) in a study conducted in Marchouch South East, Morocco. The findings reported that the net soil erosion rates were $14 \mathrm{t} / \mathrm{ha} / \mathrm{yr}$ and $12 \mathrm{t} / \mathrm{ha} / \mathrm{yr}$ when ${ }^{137} \mathrm{Cs}$ and ${ }^{210} \mathrm{~Pb}$ were respectively used in assessing the soil redistribution in agricultural fields. The study further highlighted that water erosion is the leading process of soil redistribution in cultivated fields. In addition, Benmansour et al. (2013) conducted a research on estimating soil redistribution rates and assessment of effectiveness on soil conservation techniques using ${ }^{210} \mathrm{~Pb}$ and ${ }^{137} \mathrm{Cs}$ isotopes in Marchouch South East from Rabat, Morocco. The net soil erosion using ${ }^{137} \mathrm{Cs}$, ${ }^{210} \mathrm{~Pb}$ and conventional method were reported to be $14.3 \mathrm{t} / \mathrm{ha} / \mathrm{yr}, 12.1 \mathrm{t} / \mathrm{ha} / \mathrm{yr}$ and $12.3 \mathrm{t} / \mathrm{ha} / \mathrm{yr}$, respectively. During the analysis of ${ }^{137} \mathrm{Cs}$, Mass Balance Model $\left(\mathrm{MBM}_{2}\right)$ and $\mathrm{MBM}_{3}$ conversion models were used. The models yielded net soil redistributions of $14.3 \mathrm{t} / \mathrm{ha} / \mathrm{yr}$ and $15.5 \mathrm{t} / \mathrm{ha} / \mathrm{yr}$, respectively. Within the reference site, it was observed that ${ }^{137} \mathrm{Cs}$ and ${ }^{210} \mathrm{~Pb}$ were mainly distributed in the first $10 \mathrm{~cm}$ of the soil depth where the highest concentration was close to the surface and it then diminished with increase in soil depth. They reported that gross erosion and deposition rates in the study area were 12.9 and $0.8 \mathrm{t} / \mathrm{hr} / \mathrm{yr}$ respectively. The use of combined ${ }^{137} \mathrm{Cs}$ and ${ }^{210} \mathrm{~Pb}$ FRNs indicated that a potential exists on the use of nuclides in estimating long term erosion rates in agricultural fields in Morocco. The overall data generated on soil redistribution from two nuclides was similar.

Although the concentration of ${ }^{137} \mathrm{Cs}$ is comparatively low in West African environments, results clearly differentiate zones of sediment loss and gain. The redistribution map of a hillslope in southwestern Burkina Faso shows maximum erosion rates of $16 \mathrm{t} \mathrm{ha}^{-1} \mathrm{yr}^{-1}$ at the summit and shoulder position of the hillslope and maximum deposition rates of more than $20 \mathrm{t} \mathrm{ha}^{-1} \mathrm{yr}^{-1}$ at the foot slope/valley position (Benmansour et al., 2013)

Benmansour et al., 2014 (in IAEA) assessed long term soil redistribution in a small agricultural field in Morocco using both ${ }^{137} \mathrm{Cs}$ and ${ }^{210} \mathrm{~Pb}$. 45 samples were collected along five (5) parallel transects and their activity was measured. The activities were converted into soil redistribution rates using MBM2. They found that ${ }^{210} \mathrm{~Pb}$ inventories in the study field ranged between 1700 and $5000 \mathrm{~Bq} / \mathrm{m}^{2}$. This had a mean relative uncertainty for ${ }^{210} \mathrm{~Pb}$ ranging from 4.6 to $6.6 \%$. The erosion rate was reported to range between 8 and $27 \mathrm{t} / \mathrm{ha} / \mathrm{yr}$. Also, in Marchouch Morocco, the ${ }^{7} \mathrm{Be}$ was reported by Benmansour et al. (2011) in IAEA, (2011) to be successful in quantifying erosion rates during individual or heavy rainfall events. The potential of using ${ }^{7} \mathrm{Be}$ in assessing the effectiveness of soil conservation measures was also demonstrated in Morocco in a FAO/IAEA Conducted Research Project (Mabit et al., 2014d). The ${ }^{7} \mathrm{Be}$ was found in the first few centimetres of top soil since it has a short halflife and it does not easily move deep down before it de- grades. Thus, the findings of availability of these nuclides with depth indicate that during radiometric analysis of soil and sediment samples, the top part of soil/sediment should be carefully analysed. In addition, during sample analysis, shorter interval sectioning along the depth should be adopted.

\section{Western Africa}

Schmengler (2011) found out that two cultivated sites at Dano and Wahable in Burkina Faso had ${ }^{137} \mathrm{Cs}$ areal activity of 200 to $1500 \mathrm{~Bq} / \mathrm{m}^{2}$ and 100 to $2100 \mathrm{~Bq} / \mathrm{m}^{2}$, respectively. In the two study areas, it was observed that the upper part of the hillslope experienced erosion leading to low ${ }^{137} \mathrm{Cs}$ inventories while the lower part of the hillslope had higher ${ }^{137} \mathrm{Cs}$ inventories indicating deposition. Schmengler (2011) reported that the middle part had a balance between erosion process and sediment deposition from the upslope. The net erosion rates for the hill slopes in Dano and Wahable ranged between 2.4-3.3 t/ha/yr and 2.7-5 t/ha/yr respectively. At Bonny estuary in Nigeria, Babatunde et al. (2015), studied the different concentration ranges of various radionuclides on sediments. It was found that ${ }^{137} \mathrm{Cs}$ activity concentration, was lowest in all the study sites. The ${ }^{137} \mathrm{Cs}$ ranged between $39-67 \mathrm{~Bq} / \mathrm{kg}$ while ${ }^{226} \mathrm{Ra}$ ranged between $193-484 \mathrm{~Bq} / \mathrm{kg}$. In addition, ${ }^{238} \mathrm{U},{ }^{232} \mathrm{Th}$ and ${ }^{40} \mathrm{~K}$ were analysed, the results showed a range between $383-812 \mathrm{~Bq} / \mathrm{kg}, 370-819 \mathrm{~Bq} / \mathrm{kg}$ and $300-9800 \mathrm{~Bq} / \mathrm{kg}$ for each of the radionuclides, respectively. The elevated ${ }^{238} \mathrm{U}$, ${ }^{232} \mathrm{Th}$ and ${ }^{40} \mathrm{~K}$ in the region, could be attributed to the presence of cement factories along the banks of the estuary. They reported that cement has high background values of the three nuclides which are associated with limestone, shale, clay, gypsum and other cement raw materials. They reported that the concentration of ${ }^{238} \mathrm{U}$, ${ }^{232} \mathrm{Th}$ and ${ }^{40} \mathrm{~K}$ in sediment samples was higher than that in raw cement samples of Nigeria. The ${ }^{137} \mathrm{Cs}$ and ${ }^{226} \mathrm{Ra}$ radionuclides activity concentrations were not further discussed in the paper and no information exists to link the work to erosion and sedimentation rates. Though the results showed that these radionuclides exist in the sediment core there is need for more investigation to fully understand the results.

Further, measurable quantities of ${ }^{137} \mathrm{Cs}$ were found in soil samples from profiles in Southwest Niger with a net soil flux of $16 \pm 2 \mathrm{t} / \mathrm{ha} / \mathrm{yr}$ (Chappell et al., 1998). On the other hand, in Kugri farm, Ghana, ${ }^{137} \mathrm{Cs}$ activity was determined by counting $662 \mathrm{KeV}$ gamma emmissions in a period of 2 to 21 hours counting interval. According to Pennock (2000), and (IAEA, 2014) it was reported that though analysis was run on different sized fraction of the concentrations, no measurable ${ }^{137} \mathrm{Cs}$ was detected. This indicated that, in the region of the study, the ${ }^{137} \mathrm{Cs}$ would not be applicable in study of soil erosion and deposition and hence other FRNs like ${ }^{210} \mathrm{~Pb}$ should be exploited. 


\section{Southern Africa}

An assessment of soil erosion within agricultural land in two contrasting sites (Borrowdale and Chinamora) near Harare, Zimbabwe was conducted by Quine et al. (1993) using ${ }^{137} \mathrm{Cs}$. The ${ }^{137} \mathrm{Cs}$ technique was reported to be applicable in studying soil erosion within the region. Borrowdle area was characterised by commercial farming and tropical red soils while Chinamora area had communal farming and granite sandy soils. Within the undisturbed regions of both study sites, the reference inventory was found to be $30 \mathrm{~Bq} / \mathrm{m}^{2}$ while the profile distribution on cultivated soils showed a mixed ${ }^{137} \mathrm{Cs}$ throughout the plough layer. In addition, applicability of ${ }^{210} \mathrm{~Pb}$ technique in assessing soil loss and deposition under different land uses was investigated by Collins et al. (2001) and Walling et al. (2003) in upper Kaleya River basin, Zambia.

Collins et al. (2001) used ${ }^{137} \mathrm{Cs}$ for different land uses. The considered land uses included; commercial cultivation, communal cultivation and bush grazing. The sample count time of $50,000 \mathrm{~s}$ was used due to low activity of nuclide. During the study, general guidelines and criteria by Walling and Quine (1993) for identifying representative reference sites were followed. 36 core samples were collected in sites with minimum slopes, fully vegetated and where no deposition and erosion has taken place. Sampling was stratified along the transect to cover areas below where communal cultivation, commercial cultivation and bush grazing land use were practiced. The theoretical MBM for ${ }^{137} \mathrm{Cs}$ was used. The gross erosion, net soil loss and deposition within communal cultivated site reported to be 7.0, 2.5 and $4.5 \mathrm{t} / \mathrm{ha} / \mathrm{yr}$ while that of commercial cultivation was 7.0, 4.3 and $2.7 \mathrm{t} / \mathrm{ha} / \mathrm{yr}$ respectively. In bush grazing site, gross erosion was lowest at $3.4 \mathrm{t} / \mathrm{ha} / \mathrm{yr}$ and net soil loss and deposition was reported to be 2.9 and $0.5 \mathrm{t} / \mathrm{ha} / \mathrm{yr}$. These results were based on transects sampled within areas characterised by a given land use and not on the entire topographic unit (slope to river channel)

Walling et al. (2003) compared ${ }^{137} \mathrm{Cs}$ and ${ }^{210} \mathrm{~Pb}$ in estimating the net soil redistribution under different land uses in upper Kaleya River basin, Zambia. The results from commercial cultivation gave soil loss amounts of $4.3 \mathrm{t} / \mathrm{ha} / \mathrm{yr}$ and $4.5 / \mathrm{ha} / \mathrm{yr}$ while those of communal cultivation were $2.5 \mathrm{t} / \mathrm{ha} / \mathrm{yr}$ and $1.2 \mathrm{t} / \mathrm{ha} / \mathrm{yr}$, respectively. Further, bush grazing had a net soil redistribution of $2.9 \mathrm{t} / \mathrm{ha} / \mathrm{yr}$ and $3.7 \mathrm{t} / \mathrm{ha} / \mathrm{yr}$ respectively. In the study using ${ }^{210} \mathrm{~Pb}$, soil deposition was found to be $3.7,5.2$ and $4.5 \mathrm{t} / \mathrm{ha} / \mathrm{yr}$ in commercially, communal cultivated and bush grazing land uses respectively. The findings by Walling et al. (2003) are comparable with those of Collins et al. (2001) who used ${ }^{137} \mathrm{Cs}$ within the same catchment. The ${ }^{137} \mathrm{Cs}$ and ${ }^{210} \mathrm{~Pb}$ has reported similar trend in gross erosion, net soil loss and deposition assessment. Also, it was reported that unsupported ${ }^{210} \mathrm{~Pb}$ can be used as an alternative to ${ }^{137} \mathrm{Cs}$ in equatorial region of Africa where ${ }^{137} \mathrm{Cs}$ inventories are very low.

\section{CONCLUSION}

A challenge still exists in selecting suitable reference sites for radionuclides. There is need for more actual measurements of erosion using different methods to improve on the quality of results. In addition, the reference sites should be selected as close as possible to the areas erosion and deposition is being assessed. Although use of FRNs have been reported to be useful in assessing soil redistribution and reservoir sedimentation in different regions of world, there is a long way to go in applying FRNs in Africa. Hence more research is required to exploit the use of FRNs for soil erosion and reservoir sedimentation analysis. Some of the FRNs that have been used include, ${ }^{137} \mathrm{Cs},{ }^{210} \mathrm{~Pb}$ and ${ }^{7} \mathrm{Be}$. Most of these radionuclide activities in Africa have been found detectable up to a maximum depth of $30 \mathrm{~cm}$. Morocco in Northern Africa is one of the country in which a lot has been done from 2000s' in the use of FRNs in soil erosion and soil redistribution assessment. In the southern Africa, high ${ }^{137} \mathrm{Cs}$ activity was reported back in 1993. This radionuclide activity could have diminished with time hence the need for a more current study.

In the summarised review on African continent, most studies that have been conducted, are on use of ${ }^{137} \mathrm{Cs}$ fallout radionuclide. In some cases, comparative study has been undertaken using ${ }^{137} \mathrm{Cs}$ and ${ }^{210} \mathrm{~Pb}$. The results from the reference inventory measured, indicated that ${ }^{210} \mathrm{~Pb}$ activity is higher than the ${ }^{137} \mathrm{Cs}$ activity. Also in some regions, the ${ }^{137} \mathrm{Cs}$ activity was reported to be below the minimum detection limit implying that the technique cannot be used in assessing soil erosion and deposition and that more studies/research are required for the region. Further, the highest ${ }^{137} \mathrm{Cs}$ activity in the reference site has been reported in Niger at a value of $2066 \pm 125 \mathrm{~Bq} / \mathrm{m}^{2}$ a region that is in the northern hemisphere which received more of ${ }^{137} \mathrm{Cs}$ activity than southern hemisphere.

Though the application of ${ }^{137} \mathrm{Cs}$ in the southern hemisphere is minimal, due to its low ${ }^{137} \mathrm{Cs}$ activity, the use of other fallout radionuclides such as ${ }^{210} \mathrm{~Pb}$ and ${ }^{7} \mathrm{Be}$ need to be explored. As a result, more studies are required in Africa on application of ${ }^{210} \mathrm{~Pb}$ in areas that would be representative of the whole continent to better understand soil erosion processes and reservoir sedimentation. Also, ${ }^{7} \mathrm{Be}$ nuclide is least applied within Africa. Thus, to understand short term effects on soil loss/redistribution, ${ }^{7} \mathrm{Be}$ should be analysed. To improve on assessing soil loss, redistribution and deposition analysis in Africa, FRNs should be highly exploited. From the reviewed literature on Africa use of FRNs, only in Lake Naivasha Kenya, have they been applied to study sedimentation and sediment chronology. This indicates that there is need to link use of FRNs in the erosion and deposition studies within the catchment to sedimentation of reservoirs. This can be achieved by analysing more sediment cores from reservoirs to generate sedimentation rates and chronology. 


\section{REFERENCES}

Apostu BAM, Radulescu I, Margineanu R, Ionita I and Popescu IV, 2012. Assessment of sedimentation rate through the use of anthropogenic 137Cs radionuclide. Romanian Reports in Physics 64(1): 211-220.

Babatunde B, Sikoki F and Hart I, 2015. Human Health Impact of Natural and Artificial Radioactivity Levels in the Sediments and Fish of Bonny Estuary, Niger Delta, Nigeria. Challenges 6(2): 244-257, DOI 10.3390/challe6020244.

Benmansour M, Mabit L, Owens PN, Tarjan S and Walling DE, 2014. The use of excess $210 \mathrm{pb}$ (210pbex) as a soil and sediment tracer measurements. In Guidelines for Using Fallout Radionuclides to Assess Erosion and Effectiveness of Soil Conservation Strategies, IAEA-TECDOC-1741, IAEA, Vienna (pp. 3-26).

Benmansour M, Mabit L, Nouira A, Moussadek R, Bouksirate H, Duchemin M and Benkdad A, 2013. Assessment of soil erosion and deposition rates in a Moroccan agricultural field using fallout 137Cs and 210Pbex. Journal of Environmental Radioactivity 115: 97-106, DOI 10.1016/j.jenvrad.2012.07.013.

Benmansour M, Nouira A, Benkdad A, Majah MI, Bouksirat H, El Oumri M, Duchemin, M, 2011. Estimates of long and short term soil erosion rates on farmland in semi-arid West Morocco using caesium-137, excess lead-210 and beryllium-7 measurements. In Impact of Soil Conservation Measures on Erosion Control and Soil Quality, IAEA-TECDOC-1665, Vienna (pp. 159-176).

Chappell A, Warren A, Oliver MA, and Charlton M, 1998. The utility of $137 \mathrm{Cs}$ for measuring soil redistribution in southwest Niger. Geoderma 81: 313-337, DOI 10.1016/S0016-7061(97)00090-6.

Collins AL, Walling DE, Sichingabula HM and Leeks GJL, 2001. Using $137 \mathrm{Cs}$ measurements to quantify soil erosion and redistribution rates for areas under different land use in the Upper Kaleya River basin, southern Zambia. Geoderma, 104(3-4), 299-323, DOI 10.1016/S0016-7061(01)00087-8.

Denboba AM, 2005. Forest conversion - soil degradation - farmers' perception nexus: Implications for sustainable land use in the southwest of Ethiopia. Ecology and Development Series.

Dercon G, Mabit L, Hancock G, Nguyen ML, Dornhofer P, Bacchi OOS and Zhang X, 2012. Fallout radionuclide-based techniques for assessing the impact of soil conservation measures on erosion control and soil quality: an overview of the main lessons learnt under an FAO / IAEA Coordinated Research Project. Journal of Environmental Radioactivity 107: 78-85, DOI 10.1016/j.jenvrad.2012.01.008.

Gellis A, Webb R, McIntyre S and Wolfe W, 2006. Land-Use Effects on Erosion, Sediment Yields, and Reservoir Sedimentation: A Case Study in the Lago Loíza Basin, Puerto Rico. Physical Geography 27: 39-69. 10.2747/0272-3646.27.1.39.

Golosov VN, Belyaev VR, Markelov MV, Ivanova NN and Kuznetsova YS, 2011. Application of the radionuclide technique and other methods for assessing the effectiveness of soil conservation measures at the Novosil study site, Orel region, Central Russia. In Impact of Soil Conservation Measures on Erosion Control and SoilQuality, IAEA-TECDOC-1665, Vienna (pp. 311-324).

Guzman G, Quinton JN, Nearing MA, Mabit L and Gomez JA, 2013. Sediment tracers in water erosion studies: Current approaches and challenges. Journal of Soils and Sediments 13(4): 816-833, DOI 10.1007/s11368-013-0659-5.

IAEA - International Atomic Energy Agency, 1998. Use of 137 Cs in the study of soil erosion and sedimentation. IAEA-TECDOC1028 , Vienna.

IAEA - International Atomic Energy Agency, 2003. Collection and preparation of bottom sediment samples for analysis of radionuclides and trace elements. IAEA-TECDOC-1360 IAEA, Vienna.

IAEA - International Atomic Energy Agency, 2011. Impact of Soil Conservation Measures on Erosion Control and Soil Quality. IAEA-TECDOC-1665, Vienna.

IAEA - International Atomic Energy Agency, 2014. Guidelines for Using Fallout Radionuclides to Assess Erosion and Effectiveness of Soil Conservation Strategies. IAEA-TECDOC-1741, IAEA, Vienna.

ICOLD, 2009. Sedimentation and Sustainable Use of Reservoirs and River Systems. Draft Icold Bulletin, International Commission on Large Dams (ICOLD), Paris.

Jeff Jr B and Shepherd KD, 2009. Geoderma Rapid erosion modeling in a Western Kenya watershed using visible near infrared re fl ectance, classification tree analysis and 137 Cesium. Geoderma 154(1-2): 93-100, DOI 10.1016/j.geoderma.2009.10.001.

Konz N, Baenninger D, Konz M, Nearing M and Alewell C, 2010. Process identification of soil erosion in steep mountain regions. Hydrology and Earth System Sciences 14(4): 675-686, DOI 10.5194/hess-14-675-2010.

Li S, Lobb DA and Mcconkey BG, 2010. The impacts of land use on the risk of soil erosion on agricultural land in Canada. In World Congress of Soil Science, Soil Solutions for a Changing World, Brisbane, Australia, 2010 (pp. 114-117).

Lubis AA, 2006. Constant Rate of Supply (CRS) Model for Determining the Sediment Accumulation Rates in the Coastal Area Using Lead-210. Journal of Coastal Development 10(1): 9-18.

Mabit L, Benmansour M, Abril JM, Walling DE, Meusburger K, Iurian $\mathrm{AR}$ and Alewell C, 2014a. Fallout 210Pb as a soil and sediment tracer in catchment sediment budget investigations: A review. Earth-Science Reviews 138: 335-351, DOI 10.1016/j.earscirev.2014.06.007.

Mabit L, Benmansour M, Blake WH, Taylor A, Tarján SA, Toloza A and Walling DE, 2014b. The use of 7Be as a short term soil redistribution tracer. In Guidelines for Using Fallout Radionuclides to Assess Erosion and Effectiveness of Soil Conservation Strategies, IAEA-TECDOC-1741, Vienna, DOI 10.13140/2.1.2586.1122.

Mabit L, Benmansour M, Dercon G and Walling DE, 2014c. Use of 137Cs, 210Pbex and 7Be for documenting soil redistribution: The future. In Guidelines for Using Fallout Radionuclides to Assess Erosion and Effectiveness of Soil Conservation Strategies, IAEATECDOC-1741, Vienna.

Mabit L, Kieth SC, Dornhofer P, Toloza A, Benmansour M, Bernard C, Walling DE, 2014d. 137Cs: A widely used and validated mediumterm soil tracer. Guidelines for Using Fallout Radionuclides to Assess Erosion and Effectiveness of Soil Conservation Strategies, IAEA-TECDOC-1741, Vienna, DOI 10.13140/2.1.2586.1122.

Mabit L, Meusburger K, Fulajtar E and Alewell C, 2013. Earth-Science Reviews The usefulness of $137 \mathrm{Cs}$ as a tracer for soil erosion assessment: A critical reply to Parsons and Foster (2011). Earth Science Reviews 127: 300-307, DOI 10.1016/j.earscirev.2013.05.008.

Mabit L, Zapata F, Benmansour M, Bernard C, Dercon G and Walling $\mathrm{DE}, 2014$. Assessment of soil erosion and sedimentation: the role of fallout radionuclides. Guidelines for Using Fallout Radionuclides to Assess Erosion and Effectiveness of Soil Conservation Strategies, IAEA-TECDOC-1741, IAEA, Vienna.

Mahawatte P and Abeynayake K, 2010. Use of Caesium-137 technique for the assessment of soil erosion in two selected sites in Uma Oya Catchment in Sri Lanka, In 19th World Congress of Soil Science, Soil Solutions for a Changing World 1 - 6 August 2010, Brisbane, Australia. (pp. 165-168).

Marestoni LD, Appoloni CR and Andrello AC, 2009. 7Be Fallout for Superficial Soil Erosion Assessment. 2009 International Nuclear Atlantic Conference - INAC 2009 Rio de Janeiro,RJ, Brazil, September27 to October 2, 2009, 137.

Meusburger K, Mabit L, Park JH, Sandor T and Alewell C, 2013. Combined use of stable isotopes and fallout radionuclides as soil erosion indicators in a forested mountain site, South Korea. Biogeosciences 10(8): 2565-2589, DOI 10.5194/bg-10-5627-2013.

Nouira A, Sayouty EH and Benmansour M, 2003. Use of $137 \mathrm{Cs}$ technique for soil erosion study in the agricultural region of Casablanca in Morocco. Journal of Environmental Radioactivity 68(1): 11-26, DOI 10.1016/S0265-931X(03)00025-0.

Othman Z and Ismail WR, 2012. Using Environmental Radionuclides, $137 \mathrm{Cs}$ to investigate soil redistribution in agricultural plot in Kalumpang, Selangor, Malaysia. Kajian Malaysia 30(2): 45-70. 
Patrocinio AC and Andrello AC, 2009. Prelimininary Study of the Chronology of the sedimentation process in lakes. In International Nuclear Atlantic Conference - INAC, Rio de Janeiro, RJ, Brazil.

Parsons AJ and Foster IDL, 2011. Earth-Science Reviews What can we learn about soil erosion from the use of Cs? Earth Science Reviews 108(1-2): 101-113, DOI 10.1016/j.earscirev.2011.06.004.

Pennock DJ, 2000. Suitability of 137Cs redistribution as an indicator of soil quality. Acta Geologica Hispanica 35(3-4): 213-217.

Poręba GJ, 2006. Caesium-137 As a Soil Erosion Tracer: a Review. Geochronometria 25: 37-46.

Porto P and Walling DE, 2012. Validating the use of $137 \mathrm{Cs}$ and $210 \mathrm{~Pb}$ ex measurements to estimate rates of soil loss from cultivated land in southern Italy. Journal of Environmental Radioactivity 106: 4757, DOI 10.1016/j.jenvrad.2011.11.005.

Porto P, Walling DE, Alewell C, Callegari G, Mabit L, Mallimo N and Zehringer M, 2014a. Use of a 137Cs re-sampling technique to investigate temporal changes in soil erosion and sediment mobilisation for a small forested catchment in southern Italy. Journal of Environmental Radioactivity 138: 137-148, DOI 10.1016/j.jenvrad.2014.08.007.

Porto P, Walling DE, Callegari G and Catona F, 2006. Using fallout lead-210 measurements to estimate soil erosion in three small catchments in Southern Italy. Water, Air, and Soil Pollution: Focus 6: 657-667, DOI 10.1007/s11267-006-9050-5.

Porto P, Walling DE and Capra A, 2014b. Using 137Cs and 210Pbex measurements and conventional surveys to investigate the relative contributions of interrill/rill and gully erosion to soil loss from a small cultivated catchment in Sicily. Soil and Tillage Research 135: 18-27, DOI 10.1016/j.still.2013.08.013.

Quine TA, Walling DE, and Mandiringana OT, 1993. An investigation of the influence of edaphic, topographic and land-use controls on soil erosion on agricultural land in the Borrowdale and Chinamora areas, Zimbabwe, based on caesium-137 measurements. Sediment Problems. Proc. International Symposium, Yokohama, 1993, (217), 185-196.

Ritchie JC and McHenry JR, 1990. Application of Radioactive Fallout Cesium-137 for Measuring Soil Erosion and Sediment Accumulation Rates and Patterns: A Review. Journal of Environmental Quality 19: 215-233, DOI 10.2134/jeq1990.00472425001900020006x.

Ruecker GR, Park SJ, Brunner AC and Vlek PLG, 2008. Assessment of soil redistribution on two contrasting hillslopes in Uganda using Caesium-137 modelling. Erdkunde 62(3): 259-272, DOI 10.3112/erdkunde.2008.03.06.

Saç MM and İçhedef M, 2015. Application of 137Cs technique for evaluation of erosion and deposition rates within cultivated fields of Salihli region, Western Turkey. Journal of Radiation Research and Applied Sciences 8(4): 477-482, DOI 10.1016/j.jrras.2015.04.001

Sadiki A, Faleh A, Navas A and Bouhlassa S, 2007. Assessing soil erosion and control factors by the radiometric technique in the Boussouab catchment, Eastern Rif, Morocco. Catena 71(1): 1320, DOI 10.1016/j.catena.2006.10.003.

Schmengler AC, 2011. Modeling soil erosion and reservoir sedimentation at hillslope and catchment scale in semi-arid Burkina Faso. (PhD. Thesis). Rheinischen Friedrich-WilhelmsUniversität, Bonn, Germany.

Shakhashiro A and Mabit L, 2011. Analytical performance of 14 laboratories taking part in proficiency test for the determination of caesium-137 and total lead-210 in spiked soil samples. In Impact of Soil Conservation Measures on Erosion Control and Soil Quality, IAEA-TECDOC-1665, Vienna (pp. 311-324).

Stefano CD, Ferro V and Porto P, 1999. Linking Sediment Yield and Caesium-137 Spatial Distribution at Basin Scale. Journal of
Agricultural Engineering Research 74: 41-62, DOI 10.1006/jaer.1999.0436.

Stoof-Leichsenring KR, Junginger A, Olaka LA, Tiedemann R and Trauth MH, 2011. Environmental variability in Lake Naivasha, Kenya, over the last two centuries. Journal of Paleolimnology, 45(3): 353-367, DOI 10.1007/s10933-011-9502-4.

Walling DE, 1998. Use of 137Cs and other fallout radionuclides in soil erosion investigations: Progress, problems and prospects. In Use of $137 \mathrm{Cs}$ in the study of soil erosion and sedimentation, IAEATECDOC-1028, Vienna (pp. 39-62).

Walling DE, 1999. Linking land use, erosion and sediments yields in river basins. Hydrobiologia 410: 223-240, DOI 10.1007/978-94017-2163-9.

Walling DE, Collins AL and Sichingabula HM, 2003. Using unsupported lead-210 measurements to investigate soil erosion and sediment delivery in a small Zambian catchment. Geomorphology 52(3-4): 193-213, DOI 10.1016/S0169-555X(02)00244-1.

Walling DE and He Q, 1999. Using Fallout Lead-210 Measurements to Estimate Soil Erosion on Cultivated Land. Soil Science Society of America Journal 63(5): 1404, DOI 10.2136/sssaj1999.6351404x.

Walling DE, He Q and Appleby PG, 2002. Conversion Models for Use in Soil-Erosion, Soil-Redistribution and Sedimentation Investigations. In: Handbook for the assessment of soil erosion and sedimentation using environmental radionuclides. Springer, Dordrecht, DOI 10.1007/0-306-48054-9_7.

Walling DE, He Q and Quine TA, 1995. Use of caesium-137 and lead210 as tracers in soil erosion investigations. Tracer Technologies for Hydrological Systems. Proceedings of a Boulder Symposium, July 1995, IAHS Publication No. 229, (229), 163-172.

Walling DE and Quine T, 1992. The use of caesium-137 measurements in soil erosion surveys. In Erosion and sediment transport Monitoring Programmes in River Basins, Proceedings of the Oslo Symposium (pp. 143-152).

Walling DE and Quine TA, 1993. Use of Caesium-137 as a Tracer of Erosion and Sedimentation: Handbook for the Application of the Caesium-137 Technique. 196 pp., Univ. of Exeter, Exeter, England.

Walling DE, Zhang Y and He Q, 2014. Conversion models and related software. In: Guidelines for Using Fallout Radionuclides to Assess Erosion and Effectiveness of Soil Conservation Strategies, IAEATECDOC-1741, IAEA, Vienna (pp. 3-26).

Wilkinson S, Wallbrink P, Blake W and Doerr S, 2006. Impacts on water quality by sediments and nutrients released during extreme bushfires : Report 3 : Post-fire sediment and nutrient redistribution to downstream waterbodies, Nattai National Park, NSW, (September).

Zapata F and Agudo G, 2000. Future prospects for the 137 Cs technique for estimating soil erosion and sedimentation rates. Acta Geologica Hispanica 35(3-4): 197-205.

Zhang XB, Wen ZM, Feng MY, Yang QK and Zheng JJ, 2007. Application of $137 \mathrm{Cs}$ fingerprinting technique to interpreting sediment production records from reservoir deposits in a small catchment of the Hilly Loess Plateau, China. Science in China, Series D: Earth Sciences 50(2): 254-260 DOI 10.1007/s11430007-2013-5.

Zhang Y, Long Y, Yu X and Juan A, 2014. A comparison of measured137Cs and excess $210 \mathrm{~Pb}$ levels in the cultivated brown and cinnamon soils of the Yimeng Mountain area. Chinese Journal of Geochemistry 33(2): 155-162, DOI 10.1007/s1 1631-014-0671-5.

Zheng J, Qi Y, Hua L, He X, and Zhang X, 2006. Soil erosion spatial distribution character of sloping field in the Sichuan Hilly Basin: taking a cultivated slope in Neijiang as example. Wuhan University Journal of Natural Sciences 11: 984e988. 